\title{
JUURNAL_RU
}

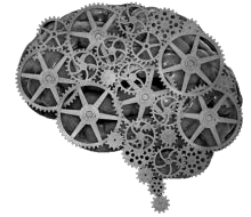

COMPANY GROUP "INTELLEKT"

Менлиосманов Э.Р. ГБОУВО РК «КИПУ» Симферополь, Россия

doi: 10.18411/lj2016-3-90

\section{Ироническая проза Сьюзен Таунсенд}

Сьюзен Лиллиан Таунсенд (2 апреля 1946 - 10 апреля 2014) британская писательница, одна из самых известных комических писателей Великобритании и мира, знаменитая благодаря созданному ею герою - несчастному подростку Адриану Моулу.

Сью Таунсенд написала множество романов и пьес, но всегда будет наиболее известна за ее персонажа Адриана Моула, который быстро стал национальным достоянием, наряду с его автором и создателем.

В «Тайный дневник Адриана Моула в возрасте 13 3/4(1982)» и «Страдания Адриана Моула(1984)», дневники Адриана подробно рассказывают, с восхитительным юмором, о мучительной боли подростковой тоски, а в более поздних книгах тоску в молодом возрасте и, даже позже, в среднем возрасте. Адриан невротик, одержим собой и примает себя слишком серьезно, еще он невероятно привлекателеный и добрый, а также воплощает образ классического британского неудачника, постоянно расстроен и растерян, и чувствует то, что другие не ценят его уникальные и особенные качества. Его личная жизнь катострофическая и он никогда не получает девушку своей мечты - Пандору Брейтуэйт, свою одноклассницу, происходящую из более богатой семьи, затем строющую себе политическую карьеру. Прежде всего, от подросткового до среднего возраста, тоска Адриана о его самоидентификации, его цели в жизни и 
состояния общества, в котором он живет - это то, к чему каждый может отнести себя, и делает его «обывателем, каждым человеком» современной Британии.

Адриан, как Таунсенд, резко наблюдательный, хотя его мысли часто становятся комично абсурдными, например, логически анализируя, почему он думает, что Уильям Хейг сын Маргарет Тэтчер. Автор, ласково высмеивает ощущение ее персонажем собственной важности - он замечает и анализирует все о себе и мире вокруг него, имеет свое мнение на все и любит считать себя интеллигентом. Он остро озабочен собой и записывает каждую деталь своих собственных мыслей и переживаний, что позволяет Таунсенд сочетать тривиальное, комическое и абсурдное с секциями, которые серьезные и острые. Например, как и большинство подростков, он беспокоится о прыщах, девочках (особенно Пандоре) и размере его анатомии. Еще он также должен выдержать травмы бурного родительского брака и прелюбодейных дел. Хотя это изображается с обычным Таунсендским остроумием, серьезностью и подлинностью эмоций, наряду с сострадательным (но не сентиментальным) тоном по отношению ко всем учавствующим персонажам. Тем не менее, все колкие и веселые личные подробности, Дневники Адриана Моула предлагают читателю гораздо больше чем опыт одного человека. Величайшей силой Таунсенд как писателя была её способность с легкостью сочетать личное с более широким, социальным и политическим контекстом. Её сатирические социальные комментарии сухие и остроумные, показывают еe невероятный четкий и проницательный взгляд на детали посредством острых наблюдений Адриана. Он также раскрывает картину того, каким образом социальнополитические вопросы влияют на жизнь и образ мыслей обыкновенного человека и обычной семьи. Ранние книги объединили весьма извечные подростковые вопросы взлетов и падений с говорящими комментариями о Великобритании времен Тэтчер в 1980-е годы, в то время как в более поздних работах используется тот же острый сатирический взгляд на новых лейбористов в 1990-х и начале XXI века, переплетающимися с заботами Адриана о браке, 
разводе, отцовстве и карьере. Все же, несмотря на проникающее видение, тон ее работ никогда не опускается в отчаение или пессимизм.

Аспект секретности, близость к читающей публики, непосредственность в дневнике и достоверность всех особенностей дневников Моула повышают удовольствие от чтения.

Добродушие Адриана также является одним из аспектов способствующих успеху. Таунсенд сама однажды намекнула на это в интервью для «Knack». Она сказала, что люди любят ее прыщавого подростка за его доброту. Он может быть несколько странным или даже слегка ненормальным, но по существу он действительно хороший мальчик. И эта доброта, по словам писателя, дает читателям некоторое чувство надежды[13].

Другим аспектом дневников, который возможно имел положительное влияние является мультилинейность сюжета. В отличие от некоторых других книг от первого лица о подростках, книги о Моуле не просто солипсические[4]. Это означает, что Адриан в своих дневниках обеспокоен не только собственной жизнью. Он также обращает внимание на переживания и чувства своих друзей и родителей. Так Таунсенд избегает монотонности и держит внимание читателя живым.

В 1989 года интервьюер Дженис Тернер спросила Таунсенд, чем она объясняет популярность книг об Адриане Моуле. Сьюзен ответила, что для нее это настоящуая загадка, но она добавила: «Люди пытались дать ответ, сказав, что есть что-то универсальное в Моуле, потому-что мы все прошли через подростковый возраст, это общий опьт»» [2].

«Мы с королевой» представляет собой роман, в котором представляется, что королевская семья была свергнута и поселена в трущобный район Лестера, после республиканской революции, хотя выясняется, что это лишь был кошмар монарха. Таунсенд была республиканкой с детсва. В интервью The Independent, опубликованной в сентябре 1992 года она рассказала, что после нахождения идеи Бога нелепой, агрументы в пользу Британской монархии также 
разрушились. «Я была поражена тем, что люди верили во все это, и я, должно быть, была одна с такими чувствами. Это было моментом откровения, но в то же время было опасно когда-либо говорить об этом». Кроме того: «учение о бесконечности, которые я считаю ошеломляющими. Заставляло меня чувствовать всех нас крошечными, крошечными частицами, и если я была крошечной, то и они - королевская семья - были тоже»[5].

В аннотации к тексту писательница подчеркивает, что все нижеследующее - «плод писательского воображения», а обстоятельства «полностью вымышленные». Точнее их можно было бы назвать «эктремальными», поскольку узнаваемых исторических героев, членов королевской семьи, автор перемещает на социальное дно, заставляя жить в переулке Ад. Все происходящее показано как некий «балаган истории», разыгрывающийся после политического переворота и падения монархии. Отстранение от власти королевы имеет зловещее предзнаменование:

«The Ravens had gone from the Tower: the kingdom would fall»

«Из Тауэра исчезли вороны: значит, королевство падет»[6].

История как бы останавливается, начинается ее осмеяние, изображение «мира наоборот».

Сьюзен Таунсенд представляет свою безумную историю в очень высоком темпе. Точно так же как в современных фильмах работа построена на коротких вспышках, которые вводят читателя многим персонажам. Неоспоримо, главным героем является королева. Это не только ее личный сон, она также достойная восхищению героиня рассказа. Медленно, но уверенно она сбрасывает искусственую видимость, которую она поддерживала в течение всей своей жизни. Она учится диалекту и социалекту ее соседей, и медленно знакомится с реальным миром. Когда в предпоследней главе, в порыве гнева, она швыряет портативный радиоприемник об стену, она, наконец, прибыла в стадию того, чтобы стать совершенно нормальным человеком. И ей это нравится, как и 
принцессе Анне, которая прекрасно выразила пустоту их прежнего сеществования:

«That's what we were, Mum. We lived in a bloody zoo to be gawped at by the public. I'm glad I'm out of it».

«А мы и были обезьянами, мама. Жили в зоопарке, и публика ходила на нас глазеть. Я рада, что вырвалась оттуда»[6, с.161].

Восклицание королевы: «- О Боже, какой кошмар!», в конце романа очень не однозначно. Слово кошмар может быть истолковано в буквальном смысле. В этом случае восклицание, является вздохом облегчения и монарх счастлив найти себя по-прежнему живущим в своем красивом изолированом месте. С другой стороны, слово может быть прочитано в переносном смысле. Тогда королева могла иметь ввиду две разные вещи. Она либо разочарована тем, что вновь окажется в «зоопарке» или ее страшит факт победы консерваторов на выборах. Эти две последние интерпретации не только вполне возможно, они даже подтверждаются тем фактом, что королева натянула ее одеяло на голову. На мой взгляд, этот жест указывает на то, что королева не хочет смотреть в лицо реальности. Она прячется под одеялом, потому что она больше не хочет жить, как рыба в аквариуме. Она скорее предпочтет её воображаемый мир, в котором она была свободна, её жизне при дворе со всеми ограничительными правилами и этикетом. Или может быть, она отказывается иметь дело с продолжением правительства консерваторов, которое оставляет миллионы бедных людей в холоде.

Пародоксальностью и неожиданностью отличается финал романа Сьюзен Таунсенд. Согласно английской традиции это «hарpy end», который читатель ожидает меньше всего. Для него возврат к исходной ситуации - это своего рода розыгрыш. В самый напряженный, кульминационный момент действия вдруг выясняется, что все происходящее было как бы «понарошку», это иллюзия, фантазия, сон, который видит королева в ночь с 9 на 10 апреля 1992 года[1]. 
Сью Таунсенд творческий и разносторонний писатель-юморист. Ей удается развлечь читающую публику с первой до последней страницы, избегая однообразия и предсказуемости. Демонстрируя блестящее чувство юмора, Таунсенд полностью опровергает утверждение, что «женщины имеют менее развитое чувство юмора». 


\section{Литература:}

1. Ремаева Ю.Г. «Английскость» в творчестве Сью Таунсенд (на примере «Дневников Адриана Моула»), Вестник Нижегородского Университета им. Н.И. Лобачевского, 2015 Режим доступа: http://www.unn.ru/pages/elibrary/vestnik/19931778_2015_-_2-2_unicode/34.pdf

2. Janice Turner, "Making mountain out of Mole thrills", in East Anglian Daily Times, September 20, 1989.

3. Marc Reynebeau, “Mensen hebben hoop nodig”, in Knack, February 11, 1987.

4. Norma Klein, "I was a teen-age intellectual”, in The New York Times Book Review, May 26, 1986.

5. Sue Townsend "Interview/ Secret passions of a republican mole: Sue Townsend explains why she killed off the Queen Mother in a council house”, 1992. Режим доступа: http://www.independent.co.uk/life-style/interviewsecret-passions-of-a-republican-mole-sue-townsend-explains-why-she-killedoff-the-queen-1548632.html

6. Sue Townsend, The Queen and I, London, Methuan, 1992 - 164p.

7. Piers Eady “Adrian Mole author Sue Townsend dies aged 68”, 2014. Режим доступа: http://www.mirror.co.uk/news/uk-news/author-sue-townsend-deadadrian-3399021 